\title{
Effect of Injection Timing and Injector Opening Pressures on the Performance of Diesel Engine Fuelled with Ceiba Pentandra Oil Methyl Ester
}

\author{
Nagesh SB ${ }^{1}$, Chandrashekhar TK${ }^{2}$, Banapurmath $\mathrm{NR}^{3 *}$ and Khandal $\mathrm{SV}^{4}$ \\ ${ }^{1}$ Department of Mechanical Engineering Channabasaveshwara institute of Technology, India \\ ${ }^{2}$ Department of Mechanical Engineering Mangalore institute of technology, India \\ ${ }^{3,4}$ Department of Mechanical Engineering B.V.B. College of Engineering and Technology, India
}

Submission: March 17, 2017; Published: May 31, 2017

*Corresponding author: Banapurmath NR, Department of Mechanical Engineering B.V.B. College of Engineering and Technology, Hubli, Karnataka, India, Tel: 9880726748, 9242896639; Email: nr_banapurmath@rediffmail.com

\begin{abstract}
Experiments were carried out on a compression ignition (CI) engine to study its performance at different injection timings (IT), injector opening pressures (IOP) and nozzle holes. The Ceiba Pentandra oil methyl ester (CPOME) was selected to check its suitability as CI engine fuel. The engine was operated at $1500 \mathrm{rpm}$ keeping hemispherical combustion chamber (HCC) shape and compression ratio of (CR) of 17.5 . IT of $27^{\circ} \mathrm{C}$ BTDC, IOP of 240 bar and injector of 5 holes yielded better performance.Maximum BTE for CPOME found to be 27.25, 27.6 and 28\% respectively for 3, 4 and 5 holes injector at $80 \%$ load against $31.25 \%$ for diesel with 3 holes injector and $0.3 \mathrm{~mm}$ orifice size. Smoke, HC, NOx and CO emissions for CPOMEpowered diesel engine were found to be $46 \mathrm{HSU}, 39 \mathrm{ppm}, 1088 \mathrm{ppm}$ and $0.13 \%$ volume respectively for 5 holes injector at optimized conditions. ID, CD, PP and HRR were $9.8^{\circ} \mathrm{C} \mathrm{A}, 40{ }^{\circ} \mathrm{C} \mathrm{A}, 73$ bar and $81 \mathrm{~J} /$ oCA respectively for 5 holes injector. Finally it could be concluded thatCPOME powered engine operation with optimum engine operating parameters like IT of $27{ }^{\circ} \mathrm{C}$ BTDC, IP of 240 bar, and 5 holes injector showed overall better engine performance in terms of higher BTE with reduced emissions.

Keywords: Ceiba Pentandra Oil Methyl Ester; Injection Strategies; Performance; Emission Characteristics

Abbreviations: IT: Injection Timing; IOP: Injector Opening Pressure; CR: Compression Ratio; BTE: Brake Thermal Efficiency; DI: Single-Cylinder Direct Injection; ID: Ignition Delay
\end{abstract}

\section{Introduction}

Use of biodiesel and different methods of using them in normal diesel enginecould be seen in the literature [1-6]. The effects of injection timing (IT), injector opening pressure (IOP) and compression ratio (CR) on brake thermal efficiency (BTE) of a single-cylinder direct injection (DI) diesel engine was reported. Mathematical models developed provide the relationship between the process parameters and the varied input characteristics. The RSM based result analysis reveals that retarding the IT improved the performance of diesel engine [7]. Ignition delay (ID), combustion and emission characteristics of diesel engine fueled with biodieselwerereported when engine was fuelled withbio-fuel. It was reported that fuel burning starts early and showedshorter ID [8]. The properties of Ceiba Pentandra methyl ester were well within the recommended biodiesel standard ASTM D6751 and it can be a possible source for biodiesel production [9].
There are more than 350 oil-bearing cropsidentified as potential sources for biodiesel production around the globe [10]. Biodiesel derived from unrefined Jatropha, Karanja and Polanga seed oil could suit as $\mathrm{CI}$ engine fuel and Polanga biodiesel (PB100) gives maximum cylinder pressure but ID were consistently shorter for JB100 [11]. Degummed jatropha of $20 \%$ with diesel yielded better results at high loads when IT was at $45^{\circ} \mathrm{C}$ BTDC [12]. In the experimental studies using tyre pyrolysis oil (TPO) was blended with Jatropha oil methyl ester (JOME) showed combustion and emission behavior different after 20\% TPO in the blend. BTE reduction was revealed with $30 \%, 40 \%$ and $50 \%$ TPO in the blend at full load [13]. Shorter ID and higher peak cylinder pressure were observed with JOME and its emulsions with WPO. Smoke opacity decrease was also reported whenemulsions with WPO was increased in comparison with diesel at full load [14]. A review work on 


\section{Recent Advances in Petrochemical Science}

the research in last decade was highlighted in the literature toget clean and efficient combustion in diesel engines [15]. It was reported that the biodiesel types have no impact on peak cylinder pressure and BSFC. Higher in-cylinder pressure and HRR were observed with biodiesel but BSFC for the engine was higher. Biodiesel's physical properties affect the performance of the engine much [16]. Review work provides potential guideline that enhances engine performance using different biodiesels and their blends [17]. The effect of CC shapes \& injection strategies on the performance of Uppage oil methyl ester (UOME) powered CI engine was studied and results showed that toriodal CC (TCC) yielded better engine output masurable at fuel IT of $19{ }^{\circ} \mathrm{C}$ bTDC. Injector used had 6 hole and $0.18 \mathrm{~mm}$ diameter each [18]. Biodiesel fuelled engine suffers due to poor cold flow properties and higher viscosity and yields higher nitric oxide (NO) $[19,20]$. The work on production of biodiesel with different feed stock was discussed [21-24]. However, seeds availability discouraging the use of biodiesel for engine applications [25]. Production of pyrolysis oil by different reactors and upgrading using catalyst has reported [26]. Desulfurized tyre oils with low percentages can be used as an alternative fuels in diesel engine with HC and smoke emission were slightly higher than neat diesel [27]. At high CR of 18.5, it has been reported a reduction in CO, HC and smoke were observed [28]. Operation of engine with $20 \%$ of tyre oil or more lead to deteriorated the engine combustion character [29]. By varying intake air flow rate and optimizing to $170 \mathrm{~g} / \mathrm{hr}$ resulted in NOx emission reduction by $5 \%$ when engine is operated with TPO-DEE, simultaneously increasing in HC, CO and smoke emission by $2 \%, 4.5 \%$ and $38 \%$ respectively [30]. Specific fuel consumption (SFC) of plastic oil blends was higher than the diesel and CO2, $\mathrm{CO}$ and NOx were also found higher [31]. NOx, CO and unburned HC were decreased, while $\mathrm{CO} 2$ and smoke increased when the IT was 140 BTDC fueled with plastic oil [32]. It has been reported that $\mathrm{CO}, \mathrm{HC}$ and particulate emissions were reduced by about $14.2 \%, 13.26 \%$ and $9.3 \%$ respectively when IT was advanced by $24.5^{\circ} \mathrm{C}$ A BTDC when blending tyre pyrolysis oil and Jatropha methyl esterblended with a fuel [33].

From the detailed literature review carried out, it was found that CPOME suitability for $\mathrm{CI}$ engine and the subsequent effect of different IT, IOP and nozzle hole combinations on the this biodiesel fueled engine was scarcely reported. Hence the objective of the present experimental work is to study the performance, combustion and emission characteristics of $\mathrm{CI}$ engine powered with CPOME with different IT, IOP and nozzle hole combinations.

\section{Materials and Methods}

\section{Fuels used in present study}

Ceibapentandra L also called as kekabu and kapok belongs to the Malvaceae family. It is a non-edible oil and used for biodiesel production. This is abundantly available in India and other Asian country. The seeds of Ceibapentandra contains about $28-30 \%$ oil. It contains high fiber and can be used for ethanol production. The physicochemical and fatty acid composition of Ceibapentandra and its effect on the biodiesel production were investigated by several investigators $[34,35]$. Ceibapentandra has comparatively better oxidation stability. The biodiesel was derived from the seeds of Ceibapentandra through wellestablished transesterification process called as CeibaPentandra Oil Methyl Ester (CPOME) and the properties of the same were measured at Bangalore Test House Laboratory, Bengaluru, India. (Table 1) summarize the properties of fuels used in the current investigation.

Table 1: Properties of various fuels.

\begin{tabular}{|c|c|c|c|}
\hline Sl. No. & Properties & Diesel & CPOME \\
\hline 1 & Chemical Formula & $\mathrm{C}_{13} \mathrm{H}_{24}$ & - \\
\hline 2 & Density $\left(\mathrm{kg} / \mathrm{m}^{3}\right)$ & 840 & 884.4 \\
\hline 3 & Calorific value $(\mathrm{kJ} / \mathrm{kg})$ & 43,000 & 40064 \\
\hline 4 & Viscosity at $40^{\circ} \mathrm{C}(\mathrm{cSt})$ & $2-5$ & 4.2 \\
\hline 5 & Flash point $\left({ }^{\circ} \mathrm{C}\right)$ & 75 & 202.5 \\
\hline 6 & Cetane Number & $45-55$ & \\
\hline 7 & Carbon Residue $(\%)$ & 0.1 & 0.06 \\
\hline 8 & Cloud point & -2 & 3 \\
\hline 9 & Pour point & -5 & 5 \\
\hline
\end{tabular}

\section{Experimental Set-Up and Methodology}

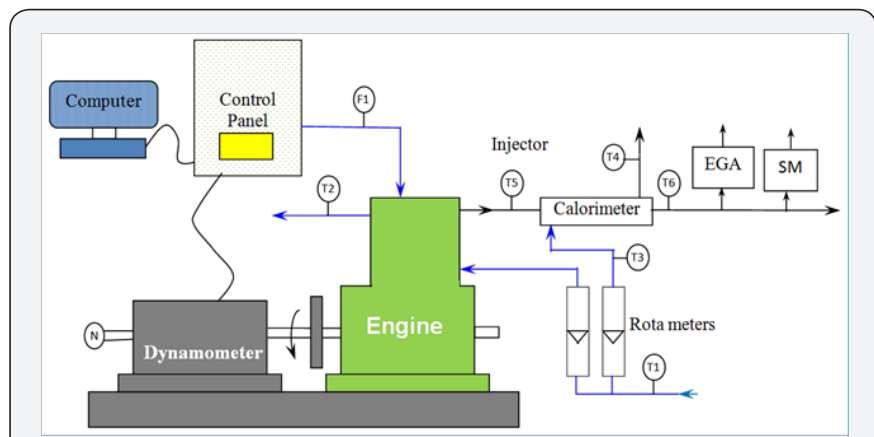

Figure 1: Experimental setup.

Experimental setup use for the current investigation is depicted in Figure 1. Initially the experimental tests were carried out on $\mathrm{CI}$ engine to optimize IT, at different loading conditionsand IT of $19^{\circ} \mathrm{C}, 23^{\circ} \mathrm{C}, 27^{\circ} \mathrm{C}$ and $31^{\circ} \mathrm{C}$ BTDC with diesel and CPOME. The engine was always operated at $1500 \mathrm{rpm}$. The CR of 17.5 was used with hemispherical combustion chamber and injector of 3 holes and $0.3 \mathrm{~mm}$ orifice size. The readings recorded only after engine attained stable condition. Further experiments were conducted to optimize IOP with 4 and 5 hole injector, keeping optimized IT. Specifications of the $\mathrm{CI}$ engine test rig used for the experimental study are shown in Table 2. Engine cooling was achieved by applying circulating water through the jackets of the engine and cylinder head. A piezoelectric transducer (Make: PCB Piezotronics, Model: HSM 111A22, Resolution: $0.145 \mathrm{mV} / \mathrm{kPa}$ ) fitted to the cylinder head was utilized to measure the in cylinder gas pressure. HRR value was calculated [36,37]. ID is the time lag between the start of fuel injection and the start of ignition. The 


\section{Recent Advances in Petrochemical Science}

start of injection was obtained based on the static fuel IT. The experimental set up of the $\mathrm{CI}$ engine is shown in Figure 1. The specifications of the engine are provided in Table 3. Exhaust gas composition during the steady-state operation was measured by employing a Hartridge smoke meter shown in Figure 2 and fivegas analyzers (A DELTA 1600 S-non dispersive infrared analyzer) shown in Figure 3.

Table 2: Specifications of the $\mathrm{Cl}$ engine.

\begin{tabular}{|c|c|c|}
\hline Sl No & Parameter & Specifications \\
\hline 1 & Type & TV1 (Kirlosker make) \\
\hline 2 & Software used & Engine soft \\
\hline 3 & $\begin{array}{l}\text { Nozzle opening } \\
\text { pressure }\end{array}$ & $200-225$ bar \\
\hline 4 & Governor type & Mechanical centrifugal type \\
\hline 5 & No. of cylinders & Single cylinder \\
\hline 6 & No. of strokes & Four stroke \\
\hline 7 & Fuel & H. S. Diesel \\
\hline 8 & Rated power & $5.2 \mathrm{~kW}(7 \mathrm{HP}$ at $1500 \mathrm{RPM})$ \\
\hline 9 & $\begin{array}{l}\text { Cylinder diameter } \\
\text { (Bore) }\end{array}$ & $0.0875 \mathrm{~m}$ \\
\hline 10 & Stroke length & $0.11 \mathrm{~m}$ \\
\hline 11 & Compression ratio & $17.5: 1$ \\
\hline \multicolumn{3}{|c|}{ Air measurement manometer } \\
\hline 12 & Made & MX 201 \\
\hline 13 & Type & U- Type \\
\hline 14 & Range & $100-0-100 \mathrm{~mm}$ \\
\hline \multicolumn{3}{|c|}{ Eddy current dynamometer } \\
\hline 15 & Model & AG -10 \\
\hline 16 & Type & Eddy current \\
\hline 17 & Maximum & $7.5(\mathrm{~kW}$ at $1500-3000 \mathrm{RPM})$ \\
\hline 18 & Flow & $\begin{array}{l}\text { Water must flow through } \\
\text { Dynamometer during the use }\end{array}$ \\
\hline 19 & $\begin{array}{l}\text { Dynamometer arm } \\
\text { length }\end{array}$ & $0.180 \mathrm{~m}$ \\
\hline 20 & $\begin{array}{l}\text { Fuel measuring unit - } \\
\text { Range }\end{array}$ & $0-50 \mathrm{ml}$ \\
\hline
\end{tabular}

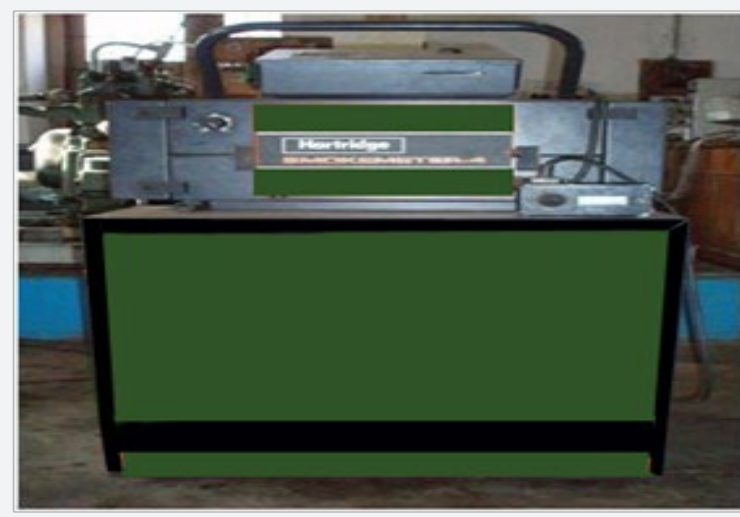

Figure 2: Hartridge Smoke meter.

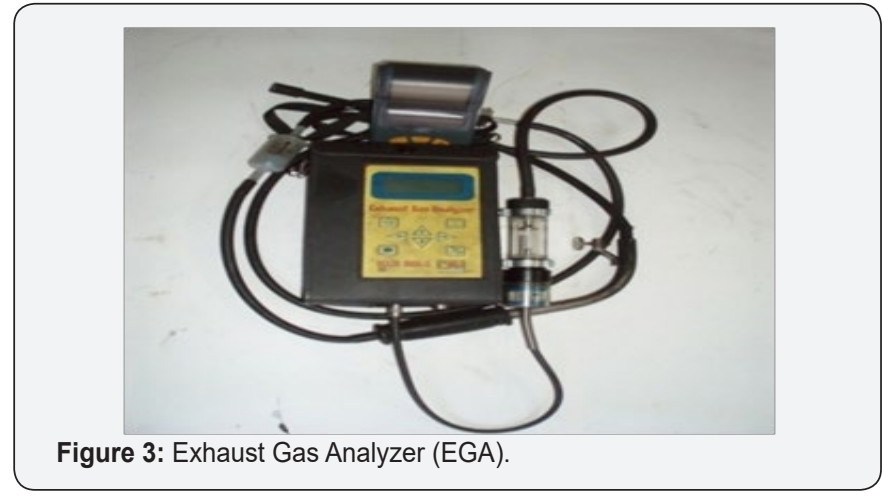

Table 3: The accuracies of the measurements and the uncertainties in the calculated parameters.

\begin{tabular}{|c|c|}
\hline Measured variable & Accuracy ( $\mathbf{\pm})$ \\
\hline Load, $\mathrm{N}$ & 0.1 \\
\hline Engine speed, $\mathrm{rpm}$ & 1 \\
\hline Temperature, ${ }^{\circ} \mathrm{C}$ & 1 \\
\hline Fuel consumption, g & 0.1 \\
\hline HFFR, kg/h & 0.001 \\
\hline Measured variable & Uncertainty (\%) \\
\hline HC & \pm 1.2 \\
\hline $\mathrm{CO}$ & \pm 2.5 \\
\hline NOx & \pm 2.3 \\
\hline Smoke & \pm 2.0 \\
\hline Calculated parameters & Uncertainty (\%) \\
\hline BTE $(\%)$ & \pm 1.2 \\
\hline HRR $\left(\mathrm{J} /{ }^{\circ} \mathrm{CA}\right)$ & \pm 1.3 \\
\hline
\end{tabular}

T1, T3 - Intake Water Temperature. T2 - Outlet Engine Jacket Water Temperature. T4 - Outlet Calorimeter Water Temperature, T5 - Exhaust Gas Temperature before Calorimeter, T6 - Exhaust Gas Temperature after Calorimeter, F1- Fuel Flow DP (Differential Pressure) unit. N - RPM encoder, EGA - Exhaust Gas Analyzer, SM - Smoke meter.

\section{Uncertainty analysis}

The uncertainties in the calculated parameters of the current investigation are provided in the (Table 3 ). In order to minimize the errors of measurements,four readings were recorded and averaged out results are only presented for the analysis.

\section{Results and Discussions}

\section{Optimization of Injection Timing (IT)}

In the first part, studies on the performance, emission and combustion characteristics of a single cylinder diesel engine when fueled with diesel, and CPOME were carried out. At the rated speed of $1500 \mathrm{rev} / \mathrm{min}$, variable load tests were conducted at fourlTs of $19{ }^{\circ} \mathrm{C}, 23{ }^{\circ} \mathrm{C}, 27{ }^{\circ} \mathrm{C}$ and $31{ }^{\circ} \mathrm{C}$ BTDC keeping IOPconstant at 205 bar. Based on the averaged out results from four readings at each of the conditions specified, optimum IT was determined. 


\section{Recent Advances in Petrochemical Science}

Effect of IT on BTE: The effect of IT on BTE for single fuel operation with diesel, and CPOME at fourITs is shown in Figure 3.1 the highest BTE is obtained with diesel at a fuel IT of $23^{\circ} \mathrm{C}$ BTDC. BTE values were lower for CPOME as compared to diesel for all four ITs. The decrease in BTE for TPOME could be due to lower energy content of the fuel. Due to higher viscosity of CPOME the formation of the mixture and subsequent burning were poorer than diesel. The maximum BTE at $23{ }^{\circ} \mathrm{C}$ BTDC is $25.25 \%$ as compared to $31.25 \%$ for diesel. However, by advancing the IT by $4{ }^{\circ} \mathrm{C} \mathrm{A}$, improvement in BTE was obtained. It is about $26.32 \%$ at an IT of $27^{\circ} \mathrm{C} \mathrm{BTDC}$. Based on the magnitudes of BTE the optimum IT for TPOME could be taken as $27^{\circ} \mathrm{C}$ BTDC.

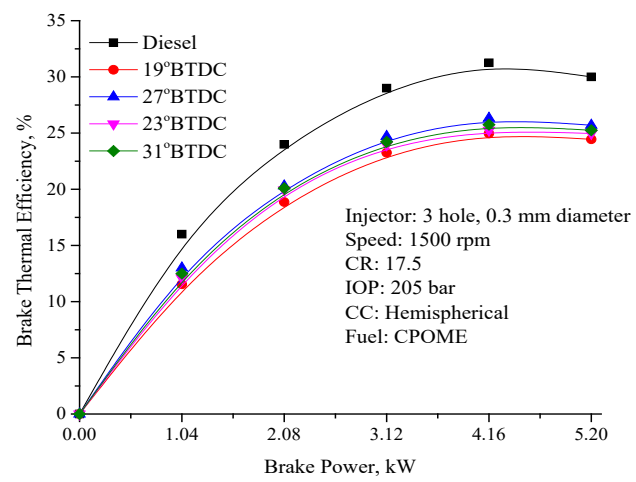

Figure 3.1: Effect of injection timing on BTE.

Effect of IT on smoke opacity: The effect of IT on smoke emission for diesel, and CPOME is shown in Figure 3.2 Smoke opacity for both fossil diesel and renewable fuel CPOME increased with increased brake power. Increased quantity of both pilot fuels injected in the engine cylinder results into increased smoke emissions. The greater smoke opacity observed with CPOME compared to diesel fuel could be mainly due to emission of higher molecules of hydrocarbons and particulate associated. Comparatively heavier molecular structure of CPOME due to its higher viscosity and density could also be responsible for the higher smoke emissions. For the same loading operation lower volatility and lower energy content of the biodiesel compared to diesel operation results into varied air-fuel ratio and hence incomplete combustion with higher smoke emissions. The smoke emission with CPOME elevated with the retarded IT. The smoke emission with CPOME is found to be minimal for retarded IT of $27^{\circ} \mathrm{C}$ BTDC as shown in Figure 3.2 it is a clear indication of relatively better combustion of fuel air mixture.The reasons for incomplete combustion is incorrect air-fuel ratio and improper mixing. It is seen that with CPOME the smoke level falls when the IT is advanced to $27^{\circ} \mathrm{C}$ BTDC from 19 and $23^{\circ} \mathrm{C}$ BTDC. However, with the further increase in IT to $31^{\circ} \mathrm{C}$ BTDC the smoke level is observed to increase due to fall in BTE, which leads to increased fuel input at a given power output.The smoke level with CPOME operation was found to be minimum at $27^{\circ} \mathrm{C}$ BTDC compared to other ITs. Smoke emission values were 63, 60, 56 and 58 HSU for IT $19{ }^{\circ} \mathrm{C}, 23^{\circ} \mathrm{C}, 27^{\circ} \mathrm{C}$ and $31^{\circ} \mathrm{C}$ BTDC respectively at $80 \%$ load.

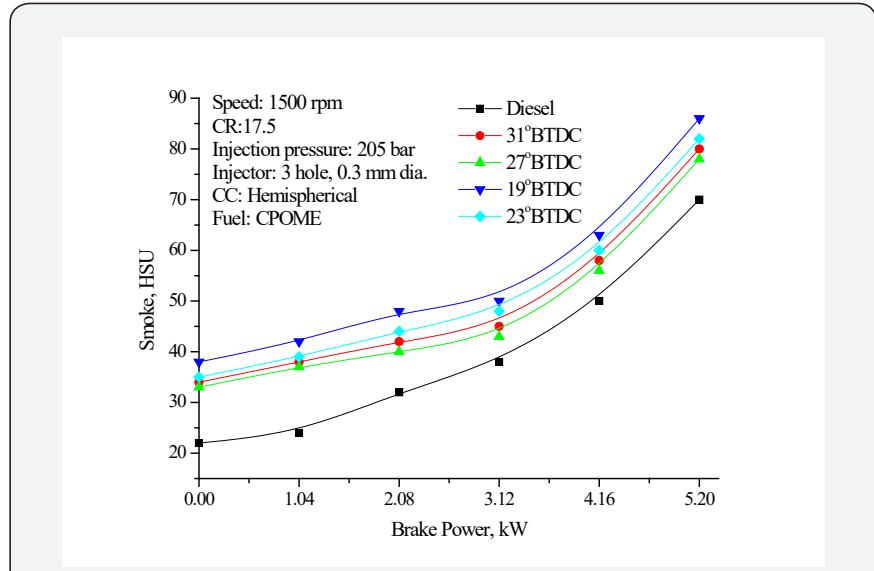

Figure 3.2: Effect of injection timing on Smoke opacity.

Effect of IT on the HC and CO: Figure 3.3 \& 3.4 demonstrates the effect of IT on HC and CO emissions for diesel, and CPOME. HC emissions exhausted from diesel engines are caused due to incomplete combustion. Lean mixture existing in the engine cylinder during ID and non-uniform mixing of fuel that leaves the fuel injector orifice at reduced velocity could also be responsible for these results.

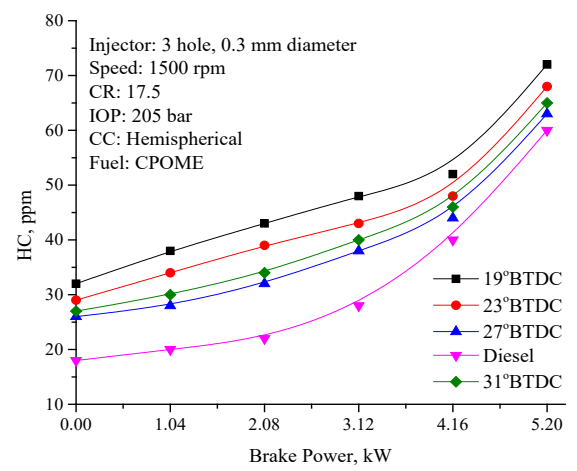

Flgure 3.3: Effect of injection timing on Unburned Hydrocarbon Emissions.

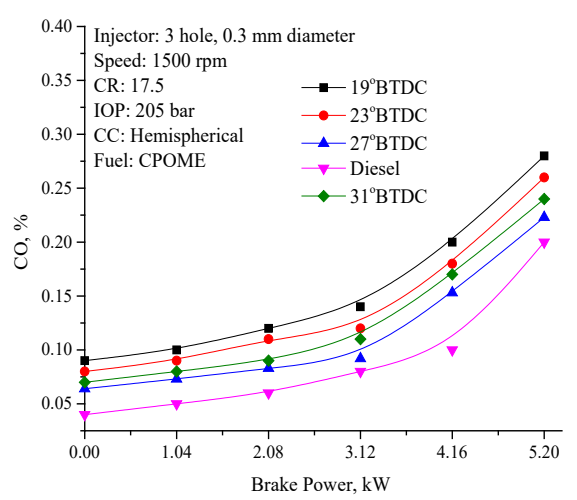

Figure 3.4: Effect of injection timing on Carbon Monoxide Emissions. 
Increased HC and CO emissions for CPOME are observed as compared to diesel for all four IT, this result could be due to decreased combustion efficiency on account of poor spray characteristics of CPOME and the injected biodiesel resulting in wall wetting. The $\mathrm{HC}$ emission values at $80 \%$ load are $52 \mathrm{ppm}, 48$ ppm $44 \mathrm{ppm}$ and $46 \mathrm{ppm}$ for $19^{\circ} \mathrm{C}, 23^{\circ} \mathrm{C}, 27^{\circ} \mathrm{C}$ and $31{ }^{\circ} \mathrm{C}$ BTDC IT respectively. Lowest $\mathrm{HC}$ levels are found at the optimum IT of $27{ }^{\circ} \mathrm{C}$ BTDC.

Carbon monoxide emissions: $\mathrm{CO}$ is a toxic by-product on account of incomplete combustion of the pre-mixed mixture prevailing inside the engine cylinder. CO emission found decreased at part loads and increased at higher loads. CPOME showed comparatively higher $\mathrm{CO}$ emissions for the probable reasons explained in $\mathrm{HC}$ emissions. The amount of $\mathrm{CO}$ at full load is $0.153 \%$ vol., $0.18 \%$ vol., $0.2 \%$ vol. and $0.3 \%$ vol. for 19 ${ }^{\circ} \mathrm{C}, 23{ }^{\circ} \mathrm{C}, 27{ }^{\circ} \mathrm{C}$ and $31{ }^{\circ} \mathrm{C}$ BTDC injection timings respectively. Lowest $\mathrm{CO}$ levels are found at the optimum injection timing of 270 BTDC. HC and CO emissions were also lowest at $27^{\circ} \mathrm{C} \mathrm{BTDC}$ as compared to other IT with CPOME as fuel.

Effect of IT on NOx Emissions: The effect of IT on emissions of nitrogen oxides with brake power for diesel, CPOME is depicted in Figure 3.5. With CPOME NOx emissions were lower compared to diesel fuel at all the ITs. Higher BTE obtained with fossil diesel and the associated higher premixed combustion phase could be responsible for the observed increased NOx trends. The main factors responsible for NOx formation are increased temperature, oxygen availability and residual time. Retarded IT showed substantial reduction in NOx emissions due to retarded combustion and lower temperature. NOx levels are 960 ppm, 1056 ppm, 1068 ppm and 1072 ppm respectivelywith CPOME operation at $80 \%$ load and IT of $19^{\circ} \mathrm{C}, 23^{\circ} \mathrm{C}, 27^{\circ} \mathrm{C}$ and $31^{\circ} \mathrm{C}$ BTDC as they lead to a sharp premixed heat release due to

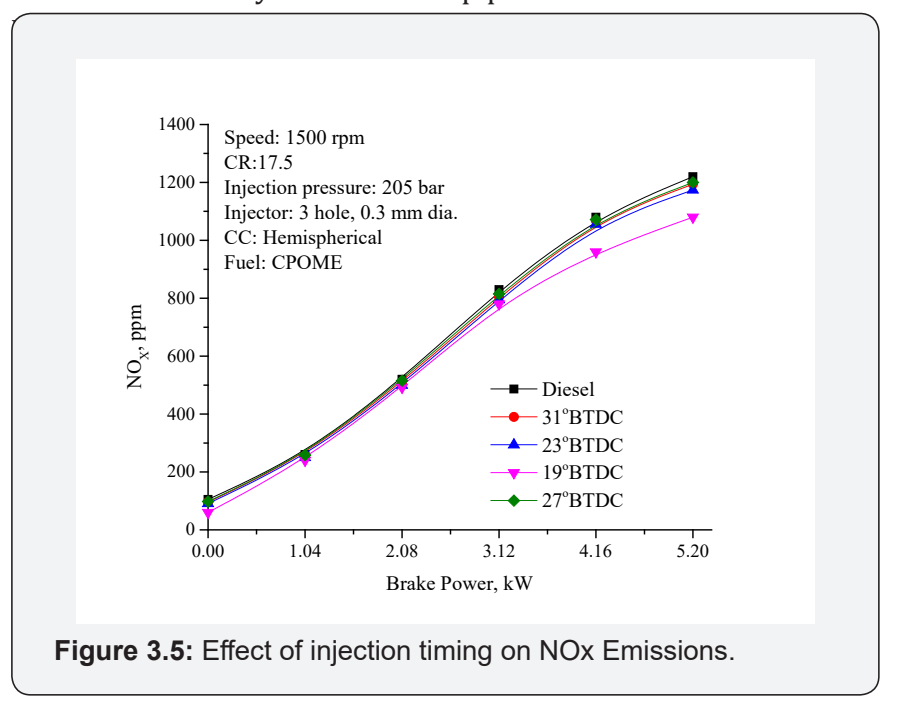

\section{Effect of IT on combustion parameters}

Peak pressure: Figure 3.6 illustrates the effect of IT on peak pressure with brake power for CPOME. Lower peak pressures were resulted with CPOME operation at all the IT compared to fossil diesel due to its lower energy content, slower burning nature and longer ID. However, when the IT is advanced the peak pressure increased as the delay period also increasedfor CPOME operation. For the retarded IT, ID redces and the engine operation was found to be noiseless and smooth.Lower pressure and temperature at the beginning of injection results with theretarded IT and hence the peak pressure lowered. PP values at $80 \%$ load are 68 bar, 70 bar, 71 bar and 70 bar for $19^{\circ} \mathrm{C}, 23^{\circ} \mathrm{C}$, $27^{\circ} \mathrm{C}$ and $31^{\circ} \mathrm{C}$ BTDC IT respectively. Highest PP levels are found at the IT of $27^{\circ} \mathrm{C}$ BTDC.

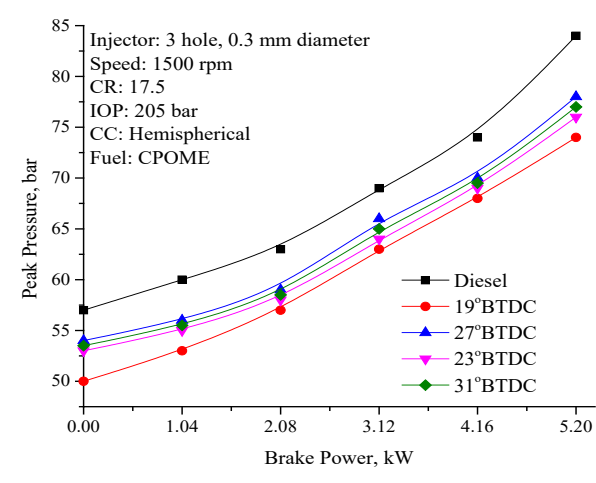

Figure 3.6: Effect of injection timing on Peak Pressure.

Ignition Delay: The effect of ITon ID with brake power is depicted in Figure 3.7 The ID is calculated based on the static IT. ID decreased with load and increased with biodiesel operation. CPOME showed longer ID as compared to diesel. However, when the IT is advanced the ID decreased as the increased BTEprovides improved combustion for CPOME operation.ID values at $80 \%$ load are $10.5^{\circ} \mathrm{CA}, 10.2^{\circ} \mathrm{CA}, 10.1^{\circ} \mathrm{C}$ A and $10.21^{\circ} \mathrm{C}$ A for $19{ }^{\circ} \mathrm{C}, 23$ ${ }^{\circ} \mathrm{C}, 27{ }^{\circ} \mathrm{C}$ and $31^{\circ} \mathrm{C}$ BTDC ITs respectively. Lower ID is found at the IT of $27^{\circ} \mathrm{C}$ BTDC.

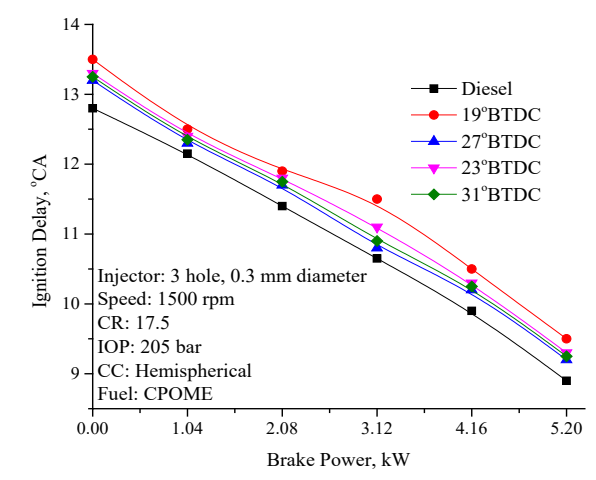

Figure 3.7: Effect of injection timing on Ignition Delay Period.

Combustion Duration: The combustion duration (CD) shown in Figure 3.8 was calculated based on the duration between the SOC and 90\% cumulative heat release. CD increased with increase in the power output with both fuels and IT as well. 
Longer CD is observed with CPOME than diesel due to longer diffusion combustion phase. It could be due to longer time for mixing and hence resulting in incomplete combustion with longer diffusion combustion phase. With the advanced IT the $\mathrm{CD}$ reduced. This could be attributed to the amount of fuel being burnt inside the cylinder gets increased. $\mathrm{CD}$ values at $80 \%$ load are $43{ }^{\circ} \mathrm{C} \mathrm{A}, 41^{\circ} \mathrm{C} \mathrm{A}, 40{ }^{\circ} \mathrm{C}$ A and $41.5^{\circ} \mathrm{C}$ A for $19{ }^{\circ} \mathrm{C}, 23{ }^{\circ} \mathrm{C}, 27{ }^{\circ} \mathrm{C}$ and $31{ }^{\circ} \mathrm{C}$ BTDC ITs respectively. Lower CD are found at the IT of $27^{\circ} \mathrm{C}$ BTDC.

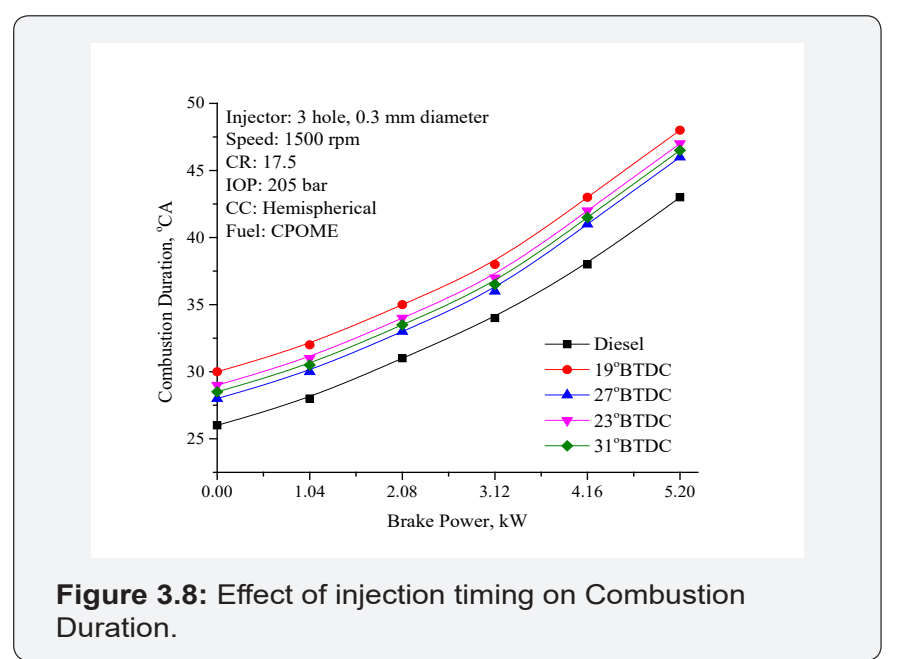

\section{Optimization of IOP}

In the second part, studies on thec performance and emission characteristics of the engine were carried out on the normal diesel engine using CPOME at different IOP. The IOPs were varied from 210 bar to 260 bar. Variable load tests were conducted at these selected IOP operating with optimized IT of $27^{\circ} \mathrm{C}$ BTDC. Based on the results, the optimum IOP was identified for CPOME. Subsequently performance, emission and combustion parameters with the CPOME were compared.Engine was operated only at manufacturer specified injector opening pressure (IOP) of 205 bar on diesel mode. The effect of IOP and different nozzle geometry such as 3,4 , and 5 holes at the static IT of $27^{\circ} \mathrm{C}$ BTDC is presented in the following graphs.

Effect of IOP and different nozzle geometry on BTE: The effect of different IOP and different nozzle geometry on BTE with brake power is demonstrated in Figure 3.9 amongst all the IOPs tested, the highest BTE was observed at IOP of 240 bar which could be due to better atomization, spray characteristics and mixing with air. Highest BTE found to be $28 \%$ at $80 \%$ load with 5-hole nozzle and at an IOP of 24MPa. However, BTE for 3-hole and 4-hole nozzles were found to be $27.25 \%$ and $27.6 \%$ respectively at $24 \mathrm{MPa}$. Based on the results, BTE was found to be high with 5-hole injector nozzle geometry and IOP of $24 \mathrm{MPa}$.

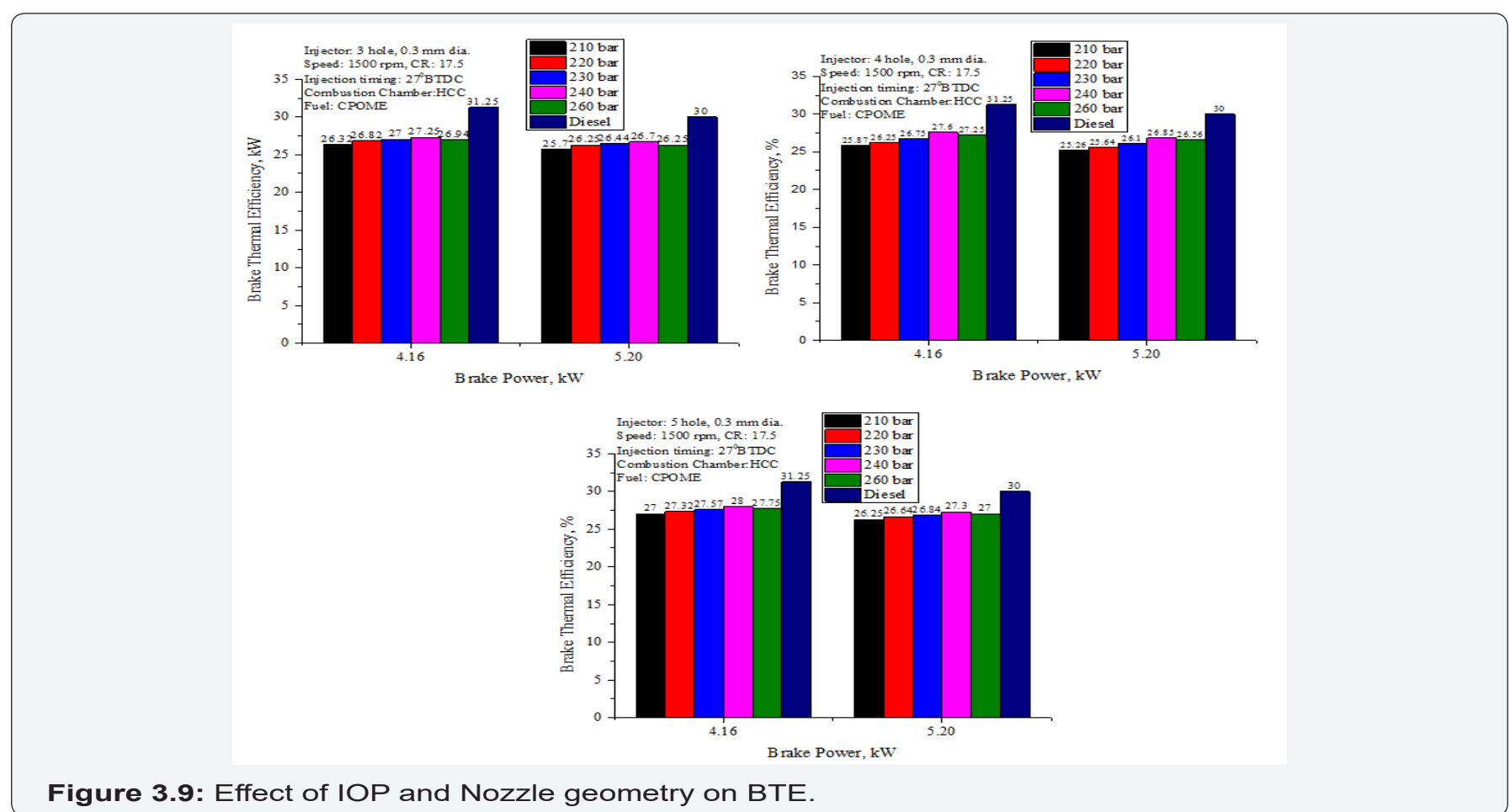

Effect of IOP and nozzle geometry on smoke opacity: Figure 3.10 shows the effect of IOP and different nozzle geometry on smoke opacity with brake power. Smoke levels were observed to fall with IOP as mixture formation improved. Lowest smoke level is seen with the IOP of 240 bar. At $80 \%$ load the smoke level was observed to fall from $53 \mathrm{HSU}$ to $46 \mathrm{HSU}$ when the IOP was increased from 210 to 240 bar with 5 holes injector. These values reported were higher than diesel operation. It is seen that 5 hole injector increased the fuel-air mixing rate and hence ensures improved combustion with reduced smoke emissions. 


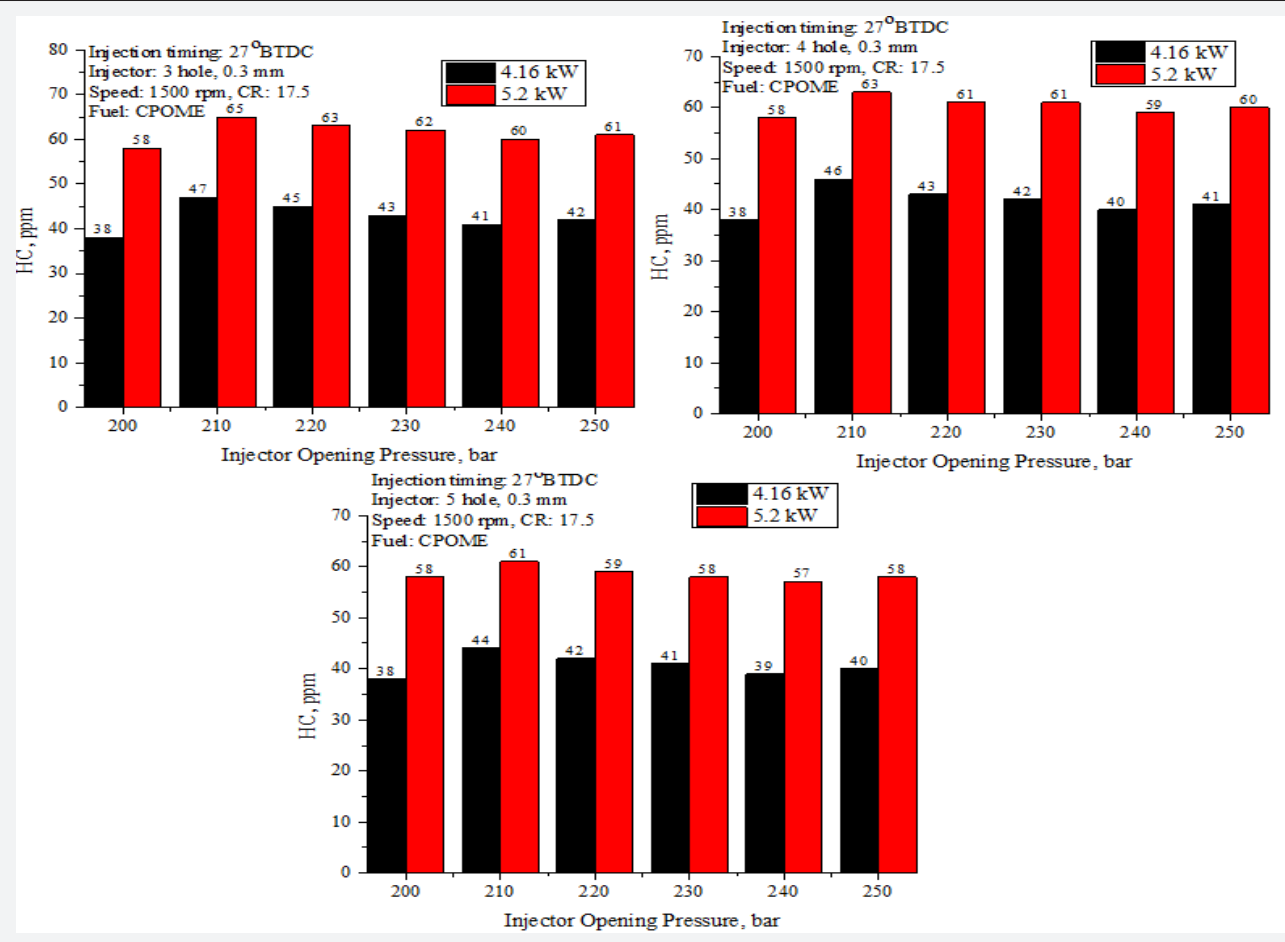

Figure 3.10: Effect of IOP and Nozzle geometry on Smoke opacit.

Effect of IOP and nozzle geometry on HC emission: injector. The highest IOP of 260 bar leads to an increase in the HC Figure 3.11 depicts the effect of IOP and nozzle geometry on HC level probably because it leads to a reduction in the BTE. Higher emission with brake power. A drop in HC was observed at 240 IOP led to a considerable portion of the combustion occurring bar IOP because of better combustion on account of enhanced in the diffusion phase on account of the short ID. It is concluded atomization. HC reduced from 44 to $39 \mathrm{ppm}$ after increasing that, un-burnt hydrocarbons were found to be less during the the IOP from 210 to 240 bar at $80 \%$ power output with 5 holes engine operation with 5-hole nozzle and IOP of $24 \mathrm{MPa}$.

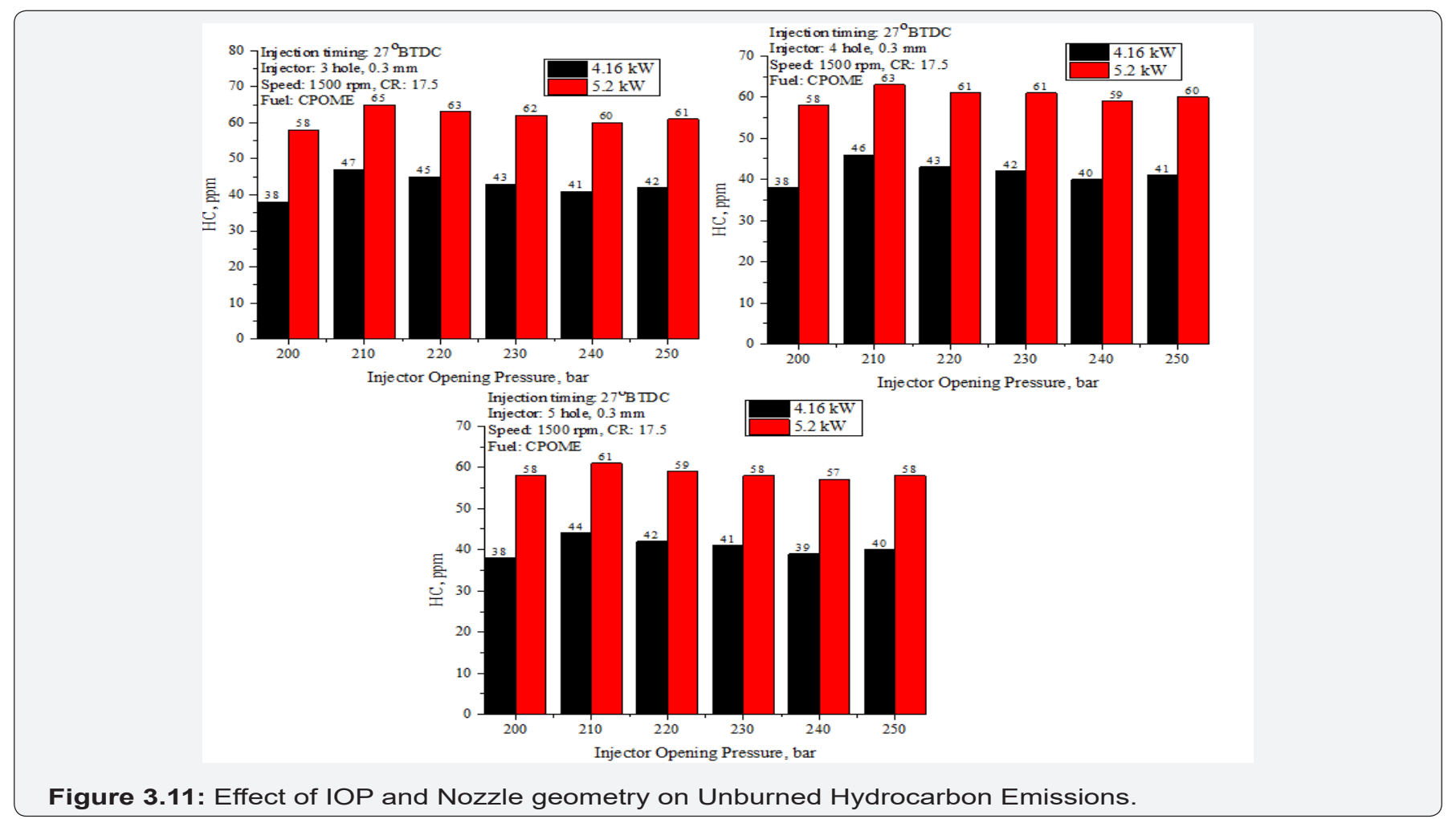




\section{Recent Advances in Petrochemical Science}

CO emission: Figure 3.12 illustrates the effect of IOP and nozzle geometry on CO Emissionwith brake power. Both $\mathrm{CO}$ and $\mathrm{HC}$ emissions were similar and lower $\mathrm{CO}$ emissions found at 240 bar IOP and 5 hole injector as usual. The lower penetration distance of fuel with 5 hole injector due to decreased mass flow rate per hole enhanced fuel air mixing rate and better combustion. This could be the reason for lower CO emission. At $80 \%$ load with 5 holes injector and 240 bar IOP, CO level was 0.13 $\%$ volume which is higher than CI mode value of $0.08 \%$ volume.

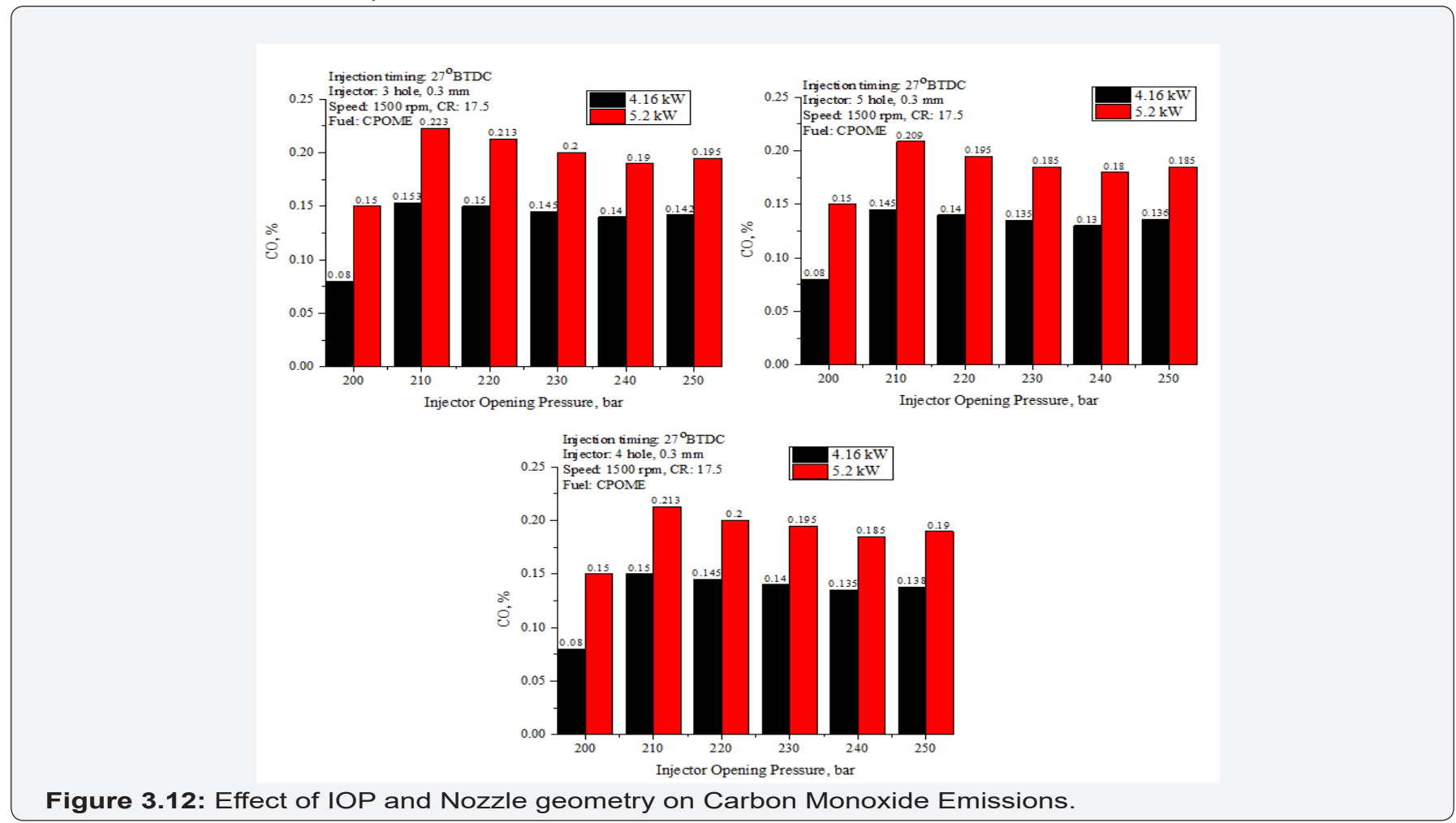

Effect of IOP and nozzle geometry on NOx emission: NOx emissions increased with the increase in IOP due to faster burning and higher temperatures reached in the cycle as shown in Fig. 3.13. Enhanced combustion prevailing inside engine cylinder and higher temperatures reached in the cycle are responsible for increased NOx. For 5-hole nozzle with same orifice size the NOx increased as the BTE is more and higher premixed combustion was observed at these conditions. At $80 \%$ load with 5 holes injector and 240 bar IOP, NOx level was $1088 \mathrm{ppm}$. This value reported was close to one obtained with $\mathrm{CI}$ mode.

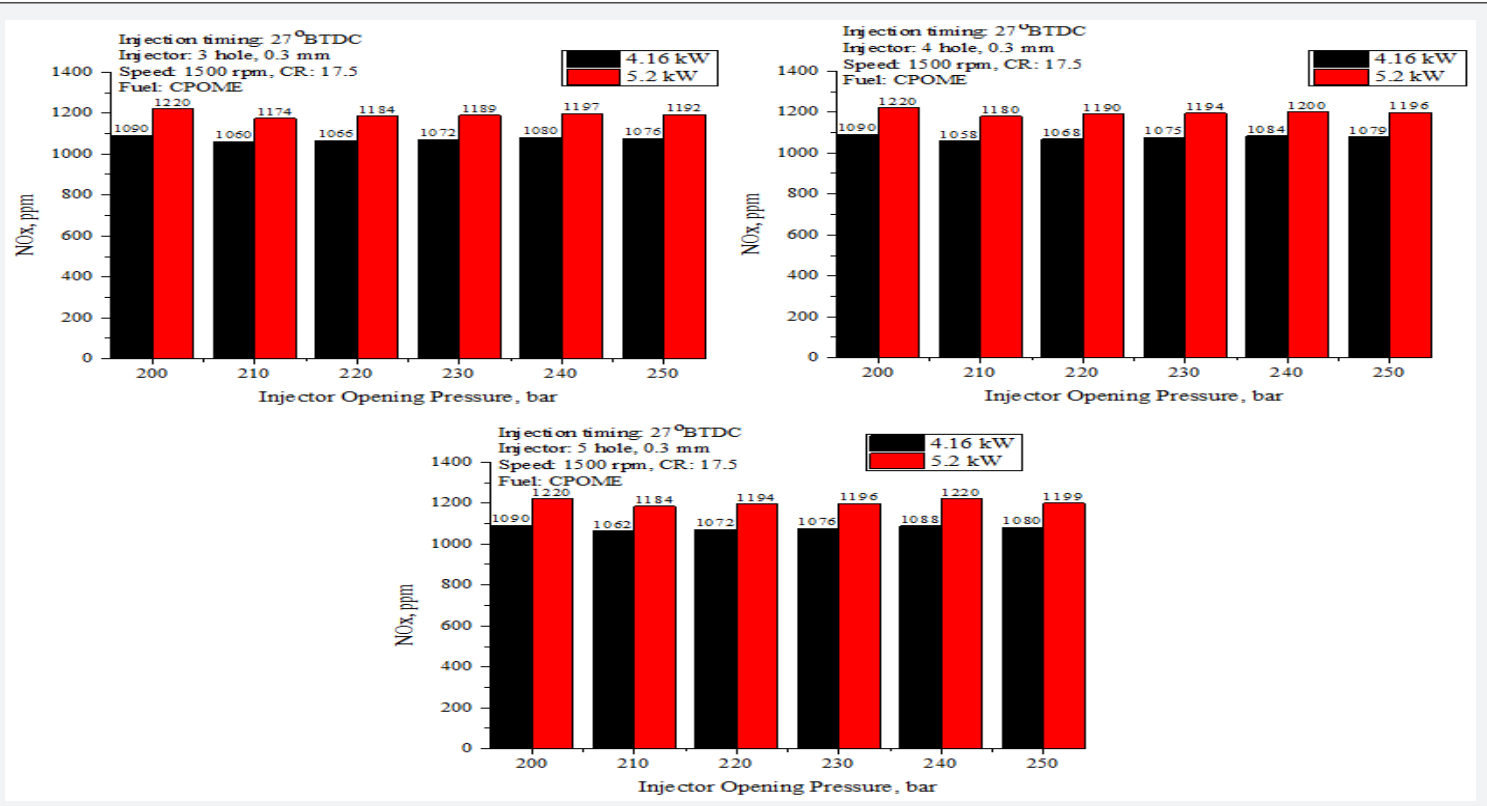

Figure 3.13: Effect of IOP and Nozzle geometry on NOx Emissions. 


\section{Recent Advances in Petrochemical Science}

Combustion characteristicsIOPs as compared to fossil diesel due to its lower calorific value and longer ID. Throughout the combustion, the peak pressure of CPOME increased with increase in fuel IOP. The increase in peak pressure was observed when the IOP was varied from $21 \mathrm{MPa}$ to $24 \mathrm{MPa}$ as shown in Figure 3.14 Beyond 24MPa the peak pressure was lowered.PP reported was73 bar at $80 \%$ load with 5-hole nozzle and at an IOP of 24MPa. However, PP for 3-hole and 4-hole nozzles were found to be 71 bar and 72 bar respectively at 24MPa. Based on the results, PP was found to be high with 5-hole injector nozzle geometry and IOP of $24 \mathrm{MPa}$.

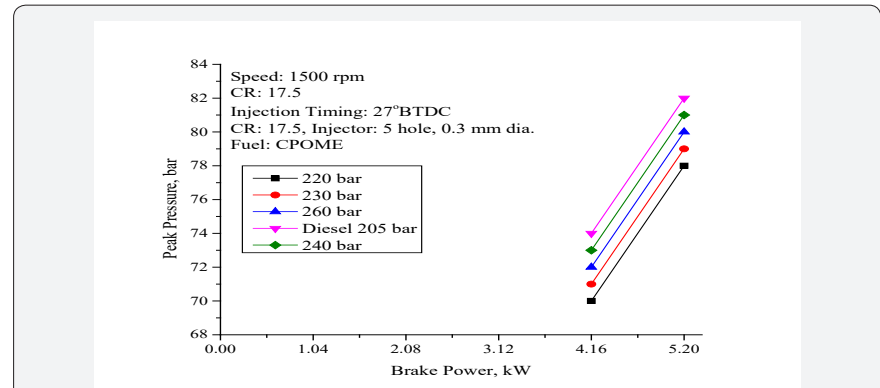

Figure 3.14: Effect of IOP and Nozzle geometry on Peak Pressure.

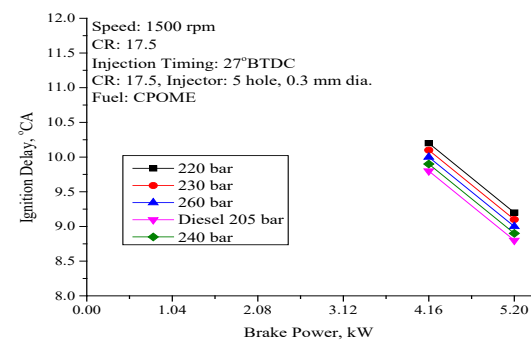

Figure 3.15: Effect of IOP and Nozzle geometry on ID Period.

b) Ignition delay: Figure 3.15 shows the effect of IOP on ID Period with brake power for CPOME operation. ID is calculated based on the static IT. ID decreased with load and increased with biodiesel operation. CPOME showed longer ID as compared to diesel. However, when the IOP is increased the ID decreased as the increased BTE provides improved combustion for CPOME operation. ID reported was $9.8^{\circ} \mathrm{CA}$ at $80 \%$ load with 5 -hole nozzle and at an IOP of $24 \mathrm{MPa}$. However, ID for 3-hole and 4-hole nozzles were found to be

$10^{\circ} \mathrm{CA}$ and $9.9^{\circ} \mathrm{CA}$ respectively at $24 \mathrm{MPa}$.

c) Combustion duration: Figure 3.16 shows the effect of IOP on CD with brake power for diesel and CPOME operation respectively. The combustion duration shown in (Figure 3.16) was calculated based on the duration between the SOC and $90 \%$ cumulative heat release. CD increased with increase in the power output with both fuels and IOP as well. Longer CD was observed with CPOME than diesel due to longer diffusion combustion phase. With the increased IOP, the CD reduced. This could be attributed to the amount of fuel being burnt inside the cylinder gets increased. CD reported was 40 ${ }^{\circ} \mathrm{CA}$ at $80 \%$ load with 5 -hole nozzle and at an IOP of $24 \mathrm{MPa}$. However, CD for 3-hole and 4-hole nozzles were found to be $42^{\circ} \mathrm{CA}$ and $41^{\circ} \mathrm{CA}$ respectively at $24 \mathrm{MPa}$.

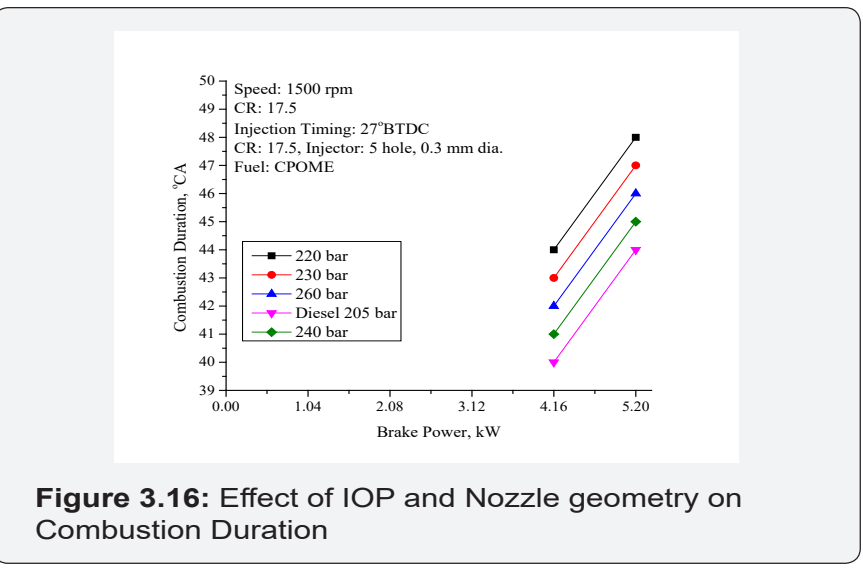

Figure 3.16: Effect of IOP and Nozzle geometry on Combustion Duration

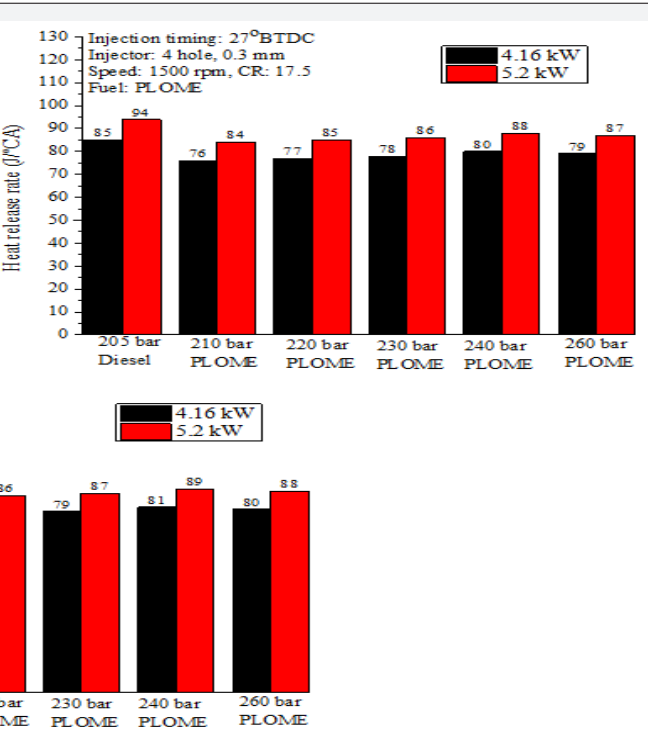

Figure 3.17: Effect of IOP and Nozzle geometry on HRR. 
d) Heat release rate: Figure 3.17 depicts the effect of IOP on HRR with brake power for diesel and CPOME operation respectively.CPOMEpowered CI engine operation resulted into higherHRRwith injector of 5 holes.Better air fuel mixture, better combustion, higher cylinder gas temperature and pressure prevailed might be the reason for the higher HRR. CPOME showed lower HRR compared to mineral diesel due to their poor combustion qualities.The HRR for CPOME found to be 79,80 and $81 \mathrm{~J} /{ }^{\circ} \mathrm{CA}$ respectively for 3,4 and 5 holes injector against $85 \mathrm{~J} /{ }^{\circ} \mathrm{CA}$ for diesel with 3 holes injector and $0.3 \mathrm{~mm}$ orifice size.

\section{Conclusion}

From the exhaustive experimental tests conducted on CPOME powered diesel engine running with 17.5 compression ratio and $1500 \mathrm{rpm}$ the following conclusions were drawn: At IOP of 240 bar, IT of $27^{\circ} \mathrm{C}$ BTDC, CR of 17.5, 3 hole injector and engine speed of $1500 \mathrm{rpm}$ following are concluded, At IOP of $205 \mathrm{bar}$, CR of 17.5 , engine speed of $1500 \mathrm{rpm}$ and load of $80 \%$ following were reported

a. CPOME can be used as substitute to diesel for CI engine with small compromise in BTE.

b. Fuel IT of $27{ }^{\circ}$ BTDC yielded better performance in terms of higher BTE and lower emissions.

c. BTE of 24.96, 25.25, 26.32 and $25.75 \%$ were achieved withIT of $19{ }^{\circ} \mathrm{C}, 23{ }^{\circ} \mathrm{C}, 27^{\circ} \mathrm{C}$ and $31^{\circ} \mathrm{C}$ BTDC respectively.

d. Smoke of 63, 60, 56 and 58 HSU were reported withIT of $19^{\circ} \mathrm{C}, 23^{\circ} \mathrm{C}, 27^{\circ} \mathrm{C}$ and $31^{\circ} \mathrm{C}$ BTDC respectively.

e. HC emissions of $52,48,44$ and 46 ppm were revealed withIT of $19{ }^{\circ} \mathrm{C}, 23^{\circ} \mathrm{C}, 27^{\circ} \mathrm{C}$ and $31^{\circ} \mathrm{C}$ BTDC respectively.

f. NOx emissions of 960, 1056, 1068 and $1072 \mathrm{ppm}$ were found withIT of $19{ }^{\circ} \mathrm{C}, 23{ }^{\circ} \mathrm{C}, 27^{\circ} \mathrm{C}$ and $31{ }^{\circ} \mathrm{C}$ BTDC respectively.

g. CO emissions of $0.153,0.18,0.2$ and $0.17 \%$ volume were obtained withIT of $19{ }^{\circ} \mathrm{C}, 23^{\circ} \mathrm{C}, 27^{\circ} \mathrm{C}$ and $31^{\circ} \mathrm{C}$ BTDC respectively.

h. PP of $68,70,71$ and 70 bar were found withIT of $19{ }^{\circ} \mathrm{C}$, $23{ }^{\circ} \mathrm{C}, 27^{\circ} \mathrm{C}$ and $31^{\circ} \mathrm{C}$ BTDC respectively.

i. ID of $10.5,10.2,10.1$ and $10.210 \mathrm{CA}$ were obtained withIT of $19^{\circ} \mathrm{C}, 23^{\circ} \mathrm{C}, 27^{\circ} \mathrm{C}$ and $31^{\circ} \mathrm{C}$ BTDC respectively.

j. $\quad \mathrm{CD}$ of $43,41,40$ and $41.5^{\circ} \mathrm{CA}$ bar obtained withIT of 19 ${ }^{\circ} \mathrm{C}, 23{ }^{\circ} \mathrm{C}, 27^{\circ} \mathrm{C}$ and $31^{\circ} \mathrm{C}$ BTDC respectively.

k. At IOP of 240 bar, IT of $27{ }^{\circ}$ CBTDC, CR of 17.5, and engine speed of $1500 \mathrm{rpm}$ following were reported,

1. Maximum BTE for CPOME found to be 27.25, 27.6 and $28 \%$ respectively for 3,4 and 5 holes injector at $80 \%$ load against $31.25 \%$ for diesel with 3 holes injector and $0.3 \mathrm{~mm}$ orifice size. m. Smoke for CPOME found to be 49,47 and $46 \mathrm{HSU}$ respectively for 3, 4 and 5 holes injector at $80 \%$ load against 40 HSU for diesel.

n. HC for CPOME found to be 41,40 and $39 \mathrm{ppm}$ respectively for 3,4 and 5 holes injector against $38 \mathrm{ppm}$ for diesel.

o. CO for CPOME found to be $0.14,0.135$ and $0.13 \%$ volume respectively for 3,4 and 5 holes injector against 0.08 $\%$ volume for diesel.

p. NOx for CPOME found to be 1080, 1084 and 1088 ppm respectively for 3, 4 and 5 holes injector against $1090 \mathrm{ppm}$ for diesel.

q. ID for CPOME found to be $10,9.9$ and $9.8^{\circ} \mathrm{CA}$ respectively for 3, 4 and 5 holes injector against $9.8 \mathrm{oC}$ A for diesel.

r. CD for CPOME found to be 42,41 and $40^{\circ} \mathrm{CA}$ respectively for 3, 4 and 5 holes injector against $38 \mathrm{oC}$ A for diesel.

s. $\quad$ PP for CPOME found to be 71,72 and 73bar respectively for 3, 4 and 5 holes injector against 74 bar for diesel.

t. HRR for CPOME found to be 79,80 and $81 \mathrm{~J} /{ }^{\circ} \mathrm{C}$ A respectively for 3,4 and 5 holes injector against $85 \mathrm{~J} /{ }^{\circ} \mathrm{C}$ A for diesel.

u. On the whole, CPOME powered engine operation with optimum engine operating parameters like IT of $27^{\circ} \mathrm{C}$ BTDC, IP of 240 bar, and 5 holes injector showed overall better engine performance in terms of higher BTE with reduced emissions.

\section{References}

1. http://www.eia.doe.gov/cabs/India/Full.html.

2. Murugesan A, Umarani C, Subramanian R, Nedunchezhian N (2009) Bio-diesel as an alternative fuel for diesel engines-A Review. Renewable and Sustainable Energy Reviews 13(3): 653-662.

3. Atadashi IM, Aroua MK, Abdul Aziz A (2010) High quality biodiesel and its diesel engine application: A review. Journal of Renewable and Sustainable Energy Reviews 14(7): 1999-2008.

4. Banapurmath NR, Tiwari PG, Vinod kumar V (2009) Combustion and emission characteristics of a direct injection $\mathrm{CI}$ engine when operated on Marotti oil methyl ester and blends of Marotti oil methyl ester and diesel. International Journal of Sustainable Engineering 2(3): 192-200.

5. Banapurmath NR, Tewari PG, Hosmath RS (2008) Combustion an emission characteristics of a direct injection, compression-ignition operated on Hongeoil, HOME and blends of HOME and diesel. International Journal of Sustainable Engineering. 1(2): 80-93.

6. Banapurmath NR, Tewari PG, Hosmath RS (2009) Effect of biodiesel derived from Hongeoil and its blends with diesel when directly injected at different injection pressures and injection timings in single-cylinder water-cooled compression ignition engine. Proc I Mech E Part A: J Power and Energy 223(1): 2009.

7. Banapurmath NR, Tiwari PG, Gaitonde VN (2012) Experimental investigations on performance and emission characteristics of Honge oil biodiesel (HOME) operated compression ignition engine. Renewable Energy 48: 193-201. 


\section{Recent Advances in Petrochemical Science}

8. Shahabuddin M (2013) Ignition delay, combustion and emission characteristics of diesel engine fueled with biodiesel. Renewable and Sustainable Energy Reviews 21(2013): 623-632.

9. Silitonga AS, Ong HC, Mahlia TMI, Masjuki HH, Chong WT, et al. (2013) Characterization and production of CeibaPentandra biodiesel and its blends. Fuel 108: 855-858.

10. YunusKhana TM, Atabanib AE, Badruddina IA, Ankalgi RF, Mainuddin Khan TK, et al. (2015) Industrial Crops and Products 65: 367-373.

11. Sahoo PK, Das LM (2009) Combustion analysis of Jatropha, Karanja and Polanga based biodiesel as fuel in a diesel engine. Fuel 88(6): 994-99.

12. Haldar SK, Ghosh BB, Nag A (2009) Studies on the comparison of performance and emission characteristics of a diesel engine using three degummed non edible oils. Biomass and BioEnergy 33(8): 10131018.

13. Sharma A, Murugan S (2013) Investigation on the behavior of a DI diesel engine fuelled with Jatropha Methyl Ester (JME) and Tyre Pyrolysis Oil (TPO) blends. Fuel 108: 699-708.

14. Prakash R, Singh RK, Murugan S (2013) Experimental investigation on a diesel engine fueled with bio-oil derived from waste wood-biodiesel emulsions. Energy 55(15): 610-618.

15. Coniglio L, Bennadji H, Glaude PA, Herbinet O, Billaud F, et al. (2013) Combustion chemical kinetics of biodiesel and related compounds (methyl and ethyl esters): Experiments and modeling-Advances and future refinements. Prog Energy Combust Sci 39(4): 340-382.

16. Tesfa B, Mishra R, Zhang C, Gu F, Ball AD, et al. (2013) Combustion and performance characteristics of $\mathrm{CI}$ (compression ignition) engine running with biodiesel. Energy 51(1): 101-115.

17. Arbab MI, Masjuk HHi, Varman M, Kalam MA, Imtenan S, et al. (2013) Fuel properties, engine performance and emission characteristic of common biodiesels as a renewable and sustainable source of fuel. Renewable and Sustainable Energy Reviews 22 : 133-147.

18. Basavarajappa DN, Banapurmath NR, Khandal SV, Manavendra G (2014) Effect of Combustion Chamber Shapes \& Injection Strategies onthe Performance of Uppage Biodiesel Operated Diesel Engines. Universal Journal of Renewable Energy, 2: 67-98.

19. Shrivastava A, Prasad R (2000) Triglycerides-based diesel fuels, Renew. Sustain. Energy Rev 4(2): 111-133.

20. Agrawal AK (2007) Biofuels (alcohols and biodiesel) applications as fuels for internal combustion engines. Prog Energy Combust Sci 33(3): 233-271.

21. Biswas PK, Pohit S, Kumar R (2010) Biodiesel from Jatropha: can India meet the 20\% blending target? Energy Policy 38(3): 1477-1484

22. Ghadge SV, Raheman H (2005) Biodiesel production from mahua (Madhucalndica) oil having high free fatty acids. Biomass Bio energy 28(6): 601-605.

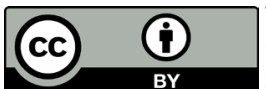

This work is licensed under Creative

Commons Attribution 4.0 Licens

DOI: 10.19080/RAPSCI.2017.01.555564
23. Srivastava PK, M. Verma M (2008) Methyl ester of karanja oil as alternative renewable source energy, Fuel 87: 1673-1677.

24. Dixit S, Rehman A (2012) Linseed oil as a potential resource for biodiesel: a review, Renew Sustain Energy Rev 16: 4415-4421.

25. Searchinger T, Heimlich R, Houghton RA, Dong F (2008) Use of U.S croplands for biofuels increases greenhouse gases through emissions from land-use change, Science 319(5867): 1238-1240.

26. Williams PT (2013) Pyrolysis of waste tyres: A review. Waste Management 33(8): 1714-1728.

27. Aydın H, Cumalillkılıc (2015) Analysis of combustion, performance and emission characteristics of a diesel engine using low sulfur tire fuel, Fuel 143: 373-382.

28. Sharma A, Murugan S (2015) Combustion, performance and emission characteristics of a DI dieselengine fuelled with non-petroleum fuel: A study on the role of fuel injection timing. Journal of the Energy Institute 88(4): 364-375

29. Frigo S, MauriziaSeggiani , Monica Puccini , Sandra Vitolo (2014) Liquid fuel production from waste tyre pyrolysis and its utilization in a Diesel engine. Fuel 116: 399-408.

30. Hariharan S, Murugan S, Nagarajan G (2013) Effect of diethyl ether on Tyre pyrolysis oil fueled diesel engine. Fuel 104: 109-115.

31. Pratoomyod J, Krongkaew Laohalidanond ING (2013) Performance and Emission Evaluation of Blends of Diesel fuel with Waste Plastic Oil in a Diesel Engine. IJESIT 2(2).

32. Mani M, Subash C, Nagarajan G (2009) Performance, emission and combustion characteristics of a DI diesel engine using waste plastic oil. Applied Thermal Engineering 29(3): 2738-2744.

33. Sharma A, Murugan S (2015) Combustion performance and emission characteristics of a DI diesel engine fuelled with non-petroleum fuel: A study on the role of fuel injection timing. Journal of the Energy Institute 88(4): 364-375.

34. Silitonga AS, Ong HC, Mahlia TMI, Masjuki HH, Chong WT, et al. (2013) Characterization and production of CeibaPentandra biodiesel and its blends. Fuel 108: 855-858.

35. Yunus khan TM, Atabani AE, Badruddin IA, Ankalgi RF (2015) Ceiba Pentandra, Nigella sativa and their blend as prospective feed stocks for biodiesel. Industrial crops and products 65: 367-373.

36. Hayes TK, Savage LD, Soreson SC (1986) Cylinder Pressure Data Acquisition and Heat Release Analysis on a Personal Computer. Society of Automotive Engineers, Paper No. 860029, USA.

37. Hohenberg GF (1979) Advanced approaches for heat transfer calculations. SAE Technical paper No: 790825.

\section{Your next submission with Juniper Publishers will reach you the below assets}

- Quality Editorial service

- Swift Peer Review

- Reprints availability

- E-prints Service

- Manuscript Podcast for convenient understanding

- Global attainment for your research

- Manuscript accessibility in different formats

( Pdf, E-pub, Full Text, Audio)

- Unceasing customer service

Track the below URL for one-step submission

https://juniperpublishers.com/online-submission.php 